\title{
Sinergi Kementerian Luar Negeri dan Kementerian Pertahanan dalam Politik Luar Negeri Indonesia
}

\author{
Agus Subagyo \\ Yusep Ginanjar \\ Universitas Jenderal Achmad Yani
}

\begin{abstract}
In the history of Indonesia's foreign policy, there are often differences in attitudes between the Ministry of Foreign Affairs and the Ministry of Defense in responding to international issues. The Ministry of Defense seems to act unilaterally and pays little attention to the Ministry of Foreign Affairs in expressing attitudes and views regarding Indonesia's foreign policy. There are disagreements between two ministries that cause polemics and pros and cons in government circles which eventually evaporate in public space. This paper analyzes the lack of synergy between the Ministry of Defense and the Ministry of Foreign Affairs in addressing international problems, which seem to work independently. This paper argues that a one-door policy in Indonesian foreign policy is needed, where the Ministry of Foreign Affairs must be positioned as the only door in the formulation and implementation of foreign policy, which the Ministry of Defense must submit to and comply with and synergy with the Ministry of Foreign Affairs in foreign policy issues.
\end{abstract}

Keywords: Ministry of Foreign Affairs, Ministry of Defense, foreign policy

\begin{abstract}
Abstrak
Dalam catatan sejarah politik luar negeri Indonesia, seringkali terjadi perbedaan sikap antara Kementerian Luar Negeri dengan Kementerian Pertahanan dalam merespon isu-isu internasional. Kementerian Pertahanan seolah-olah bersikap sepihak dan kurang memperhatikan Kementerian Luar Negeri dalam menyatakan sikap dan pandangan terkait kebijakan luar negeri Indonesia. Tidak jarang terjadi silang pendapat antara dua kementerian yang menimbulkan polemik dan pro kontra di kalangan pemerintahan yang pada akhirnya menguap di ruang publik. Tulisan ini ingin menganalisis kurang sinerginya antara Kementerian Pertahanan dan Kementerian Luar Negeri dalam menyikapi masalah internasional, yang terkesan jalan sendiri-sendiri. Tulisan ini berpendapat bahwa diperlukan kebijakan satu pintu dalam politik luar negeri Indonesia, dimana Kementerian Luar Negeri harus diposisikan sebagai satu-satunya pintu dalam perumusan dan penerapan kebijakan luar negeri, yang mana Kementerian Pertahanan harus tunduk dan patuh serta sinergi terhadap Kementerian Luar Negeri dalam isu-isu politik luar negeri.
\end{abstract}

Kata-kata kunci: Kementerian Luar Negeri, Kementerian Pertahanan, politik luar negeri 


\section{Pendahuluan}

Dalam perspektif hubungan internasional, terdapat adagium yang menyatakan bahwa politik luar negeri suatu negara merupakan kelanjutan dari politik dalam negerinya (Jemadu, 2008:42). Merah birunya politik luar negeri suatu negara sangat bergantung pada merah birunya politik dalam negeri negara tersebut (Sitepu, 2011:26). Konstelasi politik dalam negeri sangat menentukan corak politik luar negeri. Perubahan politik luar negeri sangat ditentukan oleh politik dalam negeri. Aktor-aktor yang ada di dalam negeri, seperti Presiden, Wakil Presiden, Menteri Pertahanan, Menteri Luar Negeri, parlemen, birokrasi, kelompok kepentingan, kelompok penekan, media, dan civil society, merupakan pihak yang dapat mempengaruhi politik luar negeri. Tampilan politik luar negeri sangat bergantung pada konstelasi, pergulatan, dan tarik menarik kepentingan antar elit politik, antar partai politik, dan antar kekuatan politik di dalam negeri.

Demikian pula dengan politik luar negeri Indonesia sejak Orde Lama, Orde Baru, sampai dengan Orde Reformasi penuh dengan dinamika tarik menarik kepentingan antar elit politik di dalam negeri. Problematika yang dihadapi selama ini oleh pemerintah dalam merumuskan dan mengimplementasikan politik luar negeri seringkali diwarnai oleh pergulatan dua kementerian yang saling bertentangan, yakni Kementerian Luar Negeri dan Kementerian Pertahanan. Kementerian Pertahanan semenjak Orde Baru sampai dengan saat ini masih dominan dalam urusan politik luar negeri, khususnya di bidang pertahanan, terutama berhubungan dengan kerjasama pertahanan dan diplomasi militer serta diplomasi pertahanan.

Kementerian Pertahanan seolah-olah tidak mau tunduk dan patuh dengan Kementerian Luar Negeri untuk urusan hubungan pertahanan Indonesia dengan negara lain, tidak berkoordinasi melalui Kementerian Luar Negeri ketika membahas tentang kerjasama pertahanan, pengembangan industri militer, pelatihan perang dengan negara lain, maupun pendidikan militer dengan negara lain. Kementerian Pertahanan cenderung mengabaikan Kementerian Luar Negeri dalam diplomasi dan negosiasi pembelian senjata maupun aktifitas yang melibatkan dua negara atau lebih di bidang pertahanan, sehingga Kementerian Luar Negeri seperti tidak dianggap sebagai aktor dalam politik luar negeri. Sebagai contoh, dalam pembelian persenjataan militer dari negara lain untuk kepentingan TNI, maka Kementerian Pertahanan kurang berkoordinasi dengan Kementerian Luar Negeri, khususnya Duta Besar/perwakilan diplomatik di luar negeri, untuk mengecek aspek legalitas perusahaan senjatanya, standar harga senjata yang akan dibeli, maupun untuk memastikan tidak adanya broker dalam pembelian senjata tersebut. 
Topik mengenai sinergi Kementerian Luar Negeri dengan Kementerian Pertahanan menjadi penting untuk dibahas dan didiskusikan mengingat tampilan politik luar negeri Indonesia, khususnya di bidang pertahanan sangat ditentukan oleh Kementerian Pertahanan, yang didalamnya terdapat jajaran TNI dengan tiga matra didalamnya (AD, $\mathrm{AL}, \mathrm{AU}$ ). Menariknya lagi, banyak sekali riset, buku, maupun kajian yang membahas tentang politik luar negeri, namun jarang sekali mengangkat tentang konflik dan sinergi antara Kementerian Luar Negeri dengan Kementerian Pertahanan. Sepertinya, topik ini luput dari pengamatan para pemikir, akademisi, maupun periset politik luar negeri Indonesia, yang mana politik luar negeri selama ini diulas dan dianalisis dari aspek dan perspektif yang lain, tidak dalam perspektif relasi dan sinergi antara dua kementerian tersebut.

Sejauh pembacaan dalam khazanah literatur Politik Luar Negeri Indonesia, hanya ada satu artikel dalam bentuk Karya Tulis Militer (Karlismil) yang ditulis oleh Mayor Inf. Iwan Pribadi Sartono tahun 2017 pada Jurnal Karya Vira Jati Seskoad, dengan judul “Tarik Menarik Kepentingan antara Kementerian Luar Negeri dan Kementerian Pertahahanan dalam Politik Luar Negeri Indonesia di Bidang Pertahanan Negara di Era Orde Lama dan Orde Baru." Tulisan ini menganalisis bagaimana pergulatan dan pergumulan antar kekuatan politik di Kementerian Luar Negeri dan Kementerian Pertahanan serta dominasi Kementerian Pertahanan yang selalu mengalahkan Kementerian Luar Negeri dalam perumusan dan pelaksanaan politik luar negeri di bidang pertahanan negara, khususnya diplomasi militer dan diplomasi pertahanan.

Namun demikian, artikel yang ditulis oleh Mayor Inf. Iwan Pribadi Sartono ini membahas hegemoni Kementerian Pertahanan dalam politik luar negeri pada masa Orde Lama dan Orde Baru saja, belum membahas di era Orde Reformasi. Di samping itu, tulisan tersebut hanya menganalisis tarik menarik, pergulatan, pergumulan, dan hegemoni Kementerian Pertahanan terhadap Kementerian Luar Negeri dalam politik luar negeri dibidang pertahanan semata, tanpa melihat mengapa terjadi konflik dan bagaimana sinergi antar dua kementerian tersebut dalam menciptakan politik luar negeri di bidang pertahanan yang bebas aktif.

Dalam konteks inilah, tulisan ini ingin menganalisis tentang relasi dan sinergi antara Kementerian Pertahanan dan Kementerian Luar Negeri dalam konteks politik luar negeri Indonesia, kaitannya dengan belum sinkronnya kedua kementerian ini dalam soal urusan kebijakan luar negeri, serta hambatan kedua kementerian dalam upaya sinkronisasi dalam kerangka Politik Luar Negeri Indonesia pada era reformasi. Sumbangsih tulisan ini dari aspek akademik adalah untuk menghadirkan perspektif baru dalam memandang politik luar negeri dilihat dari aspek internal, 
khususnya relasi dan sinergi antar aktor pengambil kebijakan luar negeri, yakni Kementerian Luar Negeri dan Kementerian Pertahanan.

Dalam aspek praktik kebijakan, tulisan ini dapat menyumbangkan alternatif kebijakan ataupun policy-relevant paper yang dapat bermanfaat bagi Pemerintah Indonesia, khususnya para aktor pengambil kebijakan, baik itu Kementerian Luar Negeri, Kementerian Pertahanan, kekuatan legislatif, maupun civil society dalam perumusan, pelaksanaan, dan evaluasi kebijakan luar negeri dibidang pertahanan yang selama ini sangat didominasi oleh jajaran Kementerian Pertahanan. Oleh karena itu, tulisan ini akan mencari jawaban atas pertanyaan: Bagaimana silang pendapat antara Kementerian Luar Negeri dengan Kementerian Pertahanan? Mengapa terjadi silang pendapat antara Kementerian Luar Negeri dengan Kementerian Pertahanan? Bagaimana pula langkah yang harus dilakukan agar supaya terwujud sinergi antara Kementerian Luar Negeri dengan Kementerian Pertahanan?

Tulisan ini akan terbagi menjadi enam bagian. Bagian pertama membahas kerangka pemikiran yang menguraikan tentang konsep sinergi dari beberapa pakar. Bagian kedua membahas tentang ujung tombak dalam politik luar negeri adalah Kementerian Luar Negeri di setiap negara. Bagian ketiga menjelaskan mengenai sejarah singkat Politik Luar Negeri Indonesia dari zaman Orde Lama sampai dengan Orde Reformasi. Bagian Keempat mendiskusikan mengenai silang pendapat antara Kementerian Luar Negeri dengan Kementerian Pertahanan dalam merumuskan dan mengimplementasikan Politik Luar Negeri Indonesia di bidang pertahanan negara. Bagian kelima menarasikan hambatan Kementerian Luar Negeri dan Kementerian Pertahanan dalam bersinergi membangun Politik Luar Negeri Indonesia. Bagian keenam menceritakan mengenai upaya yang harus dilakukan dalam melakukan sinergi antara Kementerian Luar Negeri dengan Kementerian Pertahanan dalam memformulasikan dan melaksanakan Politik Luar Negeri Indonesia di bidang pertahanan.

\section{Kerangka Pemikiran: Konsep Sinergi}

Menurut Covey (1989), sinergi adalah upaya menciptakan solusi, jalan keluar, dan pemecahan masalah yang bersifat kreatif dan inovatif atas permasalahan yang dialami antara dua pihak atau lebih. Sinergi merupakan kegiatan dan langkah saling melengkapi, saling mengisi, serta saling menerima masing-masing pihak tanpa adanya perasaan menang dan kalah, karena prinsipnya sinergi merupakan persamaan, kebersamaan, dan seiring sejalan untuk mencapai tujuan bersama. Menurut Walton (1999), sinergi merupakan upaya hasil dari kerjasama atau cooperative effort karena untuk menghasilkan kualitas sinergi sangat ditentukan oleh kerjasama. Sedangkan menurut Hampden-Turner (1990), sinergi berasal dari bahasa Yunani yakni syn-ergo, yang artinya adalah bekerjasama. 
Sinergi akan dapat bertahan dengan baik dan lama apabila didasari oleh semangat, komitmen, dan keterbukaan antar pihak serta menghilangkan semua sekat, perbedaan, dan hambatan yang muncul dalam relasi antara pihak yang bersinergi. Saling percaya, saling meyakini, dan saling mendukung satu dengan yang lain merupakan kunci keterpaduan antara dua pihak dalam mencapai satu tujuan. Setiap perumusan, implementasi, dan evaluasi kebijakan selalu dibahas secara bersama-sama, melibatkan semua pihak yang terkait, dan upaya saling menguatkan akan menciptakan output dan outcome yang baik berupa produk kebijakan yang akuntabel. Shaw dan Chostanzo (1970) menyatakan bahwa sinergi akan berhasil dengan baik apabila ada maintenance synergy untuk mencapai tujuan bersama. Tujuan bersama apabila terwujud maka sinergi telah mencapai pada tahapan effective synergy (sinergi efektif).

Selanjutnya Covey menyatakan bahwa sinergi harus dibangun dengan tahapan komunikasi, koordinasi, dan kolaborasi. Komunikasi dapat terbangun melalui saluran kontak baik informal maupun formal antar pihak yang terkait. Koordinasi dapat diwujudkan dengan saling melakukan pertemuan, rapat maupun kegiatan koordinatif lainnya. Sedangkan kolaborasi dilakukan dengan menggelar kegiatan bersama, program bersama, maupun aktifitas bersama untuk meningkatkan hubungan emosional maupun menciptakan karya nyata demi kebaikan organisasi.

Dalam konteks politik luar negeri, sinergi sangat dibutuhkan oleh semua aktor yang terlibat baik dalam proses perumusan kebijakan, pelaksanaan kebijakan, maupun evaluasi kebijakan luar negeri, khususnya Kementerian Luar Negeri dengan Kementerian Pertahanan. Komunikasi, koordinasi, dan kolaborasi antara Kementerian Luar Negeri dengan Kementerian Pertahanan dalam politik luar negeri, khususnya di bidang pertahanan negara sangat penting untuk dilakukan, sehingga akan terjalin inovasi, kreasi, dan terobosan dalam penggelaran diplomasi pertahanan Indonesia di era reformasi saat ini.

\section{Kementerian Luar Negeri Sebagai Ujung Tombak}

Salah satu aktor yang merupakan ujung tombak dalam politik luar negeri adalah Kementerian Luar Negeri yang dipimpin oleh seorang Menteri Luar Negeri. Kementerian Luar Negeri adalah institusi resmi dan formal dalam setiap negara yang menjalankan tugas dan fungsi politik luar negeri untuk mencapai kepentingan nasionalnya. Oleh karena itu, hampir setiap negara di dunia memiliki lembaga dan institusi Kementerian Luar Negeri dengan nama dan nomenklatur yang berbeda di masing-masing negara, namun memiliki fungsi dan tugas yang sama, yakni sama-sama menjalankan politik luar negeri, yang telah digariskan oleh pemimpin negara, baik kepala negara maupun kepala pemerintahan suatu negara. 
Diperlukan kapabilitas, kompetensi, dan integritas yang mumpuni dan profesional dari seorang Menteri Luar Negeri yang mengisi jabatan dan posisi sebagai pimpinan tertinggi di Kementerian Luar Negeri.

Berdasarkan aspek teoretis, Kementerian Luar Negeri harus mampu merumuskan, mengelola, dan menerapkan kebijakan politik luar negeri yang tertuang dalam konstitusi dan aturan perundang-undangan lainnya dengan memberdayakan segala kekuatan nasional untuk mencapai kepentingan nasionalnya. Melihat beban yang dipikul oleh Kementerian Luar Negeri yang sangat berat, khususnya membawa nama bangsa di fora internasional, maka setiap Kementerian Luar Negeri memiliki jaringan atau semacam 'kantor cabang' di luar negeri, khususnya di setiap negara yang memiliki hubungan diplomatik, yakni Kedutaan dan Konsulat di negara lain. Kedutaan dipimpin oleh Duta Besar, Konsulat Jenderal dipimpin oleh Konsul Jenderal, dan Konsulat dipimpin oleh Konsul, merupakan kepanjangan tangan Menteri Luar Negeri dalam menjabarkan aspek teknis operasional di lapangan, khususnya dalam perwujudan politik luar negeri, terutama hubungan diplomatik dengan negara penempatan.

Salah satu unsur penting yang merupakan sumber daya manusia di Kementerian Luar Negeri adalah diplomat. Diplomat adalah personil terpilih di lingkungan Kementerian Luar Negeri yang menjalankan tugas representing (mewakilinegara atau pemerintah), promoting (mempromosikan negaranya), reporting (melaporkan segala perkembangan negara tempat diplomat ditugaskan), protecting (melindungi warga negaranya di negara tempat diplomat ditugaskan), dan negotiating (melakukan perundingan membahas isu tertentu untuk mencapai kesepakatan) (Ambarwati \& Wijatmadja, 2016:11). Diplomat adalah orang yang jujur/baik, dikirim keluar negeri, untuk berbohong, demi kejayaan bangsa dan negaranya. Diplomat merupakan penentu keberhasilan politik luar negeri suatu negara, dimana keterampilan, kelihaian, keluwesan, dan kemahiran diplomat dibutuhkan untuk terwujudnya target dan capaian kesepakatan dengan negara lain dalam rangka memenuhi kepentingan nasionalnya (Jackson \& Sorensen, 2009:25).

Di samping itu, peran Duta Besar juga sangat signifikan dalam pelaksanaan politik luar negeri. Perwakilan diplomatik di luar negeri dikomando oleh seorang Duta Besar yang memiliki kompetensi, kapabilitas, dan integritas yang handal di bidang hubungan internasional. Duta Besar merupakan 'manajer' yang mengelola secara teknis hubungan diplomatik antar negara, menjalankan amanat konstitusi, mempedomani perintah kepala negara/kepala pemerintahan, dan senantiasa menjalankan komando dari Menteri Luar Negeri. Sebagai simbol yang mewakili negaranya di negara tempat ditugaskan, seorang Duta Besar dituntut untuk selalu hati-hati alias prudence dalam bertutur kata, profesional dalam menyatakan pendapat, 
proporsional dalam menjalankan tugas dan senantiasa mengedepankan dialog ketika menghadapi permasalahan yang mempengaruhi hubungan bilateral kedua negara.

\section{Sekilas Politik Luar Negeri Indonesia}

Dalam konteks Indonesia, politik luar negeri Indonesia sudah digariskan dalam konstitusi memegang prinsip 'bebas aktif'. Bebas diartikan sebagai independen/merdeka/netral dalam bersikap, bertindak dan bertingkah laku dalam setiap interaksi dengan negara lain dalam forum internasional, tanpa adanya pemihakan terhadap salah satu kekuatan/ blok tertentu. Aktif diartikan sebagai turut serta/partisipasi dalam setiap kegiatan, aktifitas dan program yang dicanangkan oleh komunitas internasional, khususnya dalam menciptakan perdamaian dunia dan ketertiban internasional. Indonesia ambil bagian dalam setiap agenda multilateral dan kesepakatan global demi terwujudnya dunia yang adil, damai, dan sejahtera, tanpa adanya kekerasan, konflik, dan peperangan antar negara. Indonesia juga berprinsip bahwa Indonesia cinta damai, tetapi lebih cinta kemerdekaan.

Dalam tataran praktis, pelaksanaan politik luar negeri Indonesia sangat dipengaruhi oleh kepemimpinan nasional yang berjalan saat itu. Di masa Orde Lama, tampilan politik luar negeri Indonesia yang cenderung ke Blok Timur sangat dipengaruhi oleh sosok Presiden Soekarno yang sangat kharismatis dan fenomenal. Pada masa Orde Baru, praktek politik luar negeri Indonesia yang condong ke Blok Barat ditentukan oleh seorang Presiden Soeharto yang sangat militeristis (Wuryandari, 2009:23). Di era reformasi, kecenderungan politik luar negeri Indonesia juga ditentukan oleh para pemimpin nasionalnya masing-masing, baik Presiden B.J Habibie, Gus Dur, Megawati Soekarno Putri, Susilo Bambang Yudhoyono, maupun Jokowi.

Era Orde Baru yang merupakan sistem politik dan pemerintahan terlama sangat membentuk corak dan warna politik luar negeri Indonesia (Eby Hara, 2011:10). Di kala itu, banyak sekali Duta Besar yang berasal dari latar belakang militer, peran berbagai lembaga militer yang mempengaruhi penerapan kebijakan luar negeri Indonesia, dan peran dari Kementerian Pertahanan yang seolah-olah 'mendikte' kebijakan luar negeri yang dijalankan oleh Kementerian Luar Negeri. Kementerian Pertahanan seolaholah memiliki kewenangan untuk menerobos berbagai kebijakan luar negeri yang telah digariskan sebelumnya dan kadangkala malah menjadi semacam 'penjuru' dalam politik luar negeri Indonesia. Berbagai keputusan luar negeri pada masa itu banyak ditentukan oleh peran dan kiprah dari Kementerian Pertahanan, sehingga membuat ruang gerak Kementerian Luar Negeri seolah-olah di-bypass oleh Kementerian Pertahanan dengan segala perangkat dan jajaran di bawahnya. 
Kenyataan inilah yang kemudian menjadi 'kebiasaan' dan 'budaya' yang sulit untuk dihilangkan sampai dengan saat ini, dimana kadangkala Kementerian Pertahanan, yang didalamnya terdapat TNI dan jajarannya, melakukan tindakan 'off side' melampaui kewenangannya, dalam urusan politik luar negeri. Kementerian Pertahanan, secara tidak sadar, menabrak kewenangan Kementerian Pertahanan, dalam urusan hubungan luar negeri ataupun urusan hubungan bilateral antar negara, tanpa berkoordinasi dan berkomunikasi terlebih dahulu dengan Kementerian Pertahanan. Kementerian Pertahanan tidak jarang mengeluarkan pernyataan sepihak yang justru bertentangan dengan pernyataan dan sikap resmi Kementerian Luar Negeri, sehingga membuat kegaduhan di dalam negeri, sebagai akibat kurang sinergisnya antara Kementerian Pertahanan dengan Kementerian Luar Negeri.

Di era reformasi saat ini, Kementerian Pertahanan sudah saatnya menyadari tugas pokok dan fungsinya dalam urusan pertahanan negara, dan bukan urusan kebijakan luar negeri. Urusan kebijakan luar negeri merupakan domain dari Kementerian Luar Negeri sehingga setiap ada permasalahan pertahanan negara yang ada kaitannya dengan urusan luar negeri, kerjasama antar negara, dan hubungan bilateral antar kedua negara, sudah saatnya berkoordinasi dan berkomunikasi dengan Kementerian Luar Negeri, sebagai kementerian yang berhak dan berwenang dalam urusan kebijakan dan politik luar negeri. Kementerian Pertahanan sudah saatnya 'menertibkan' diri untuk selalu menyalurkan sikap dan kebijakan terkait dengan hubungan bilateral antar negara dan persoalan yang terkait dengan hubungan diplomatik kepada Kementerian Luar Negeri.

\section{Silang Pendapat Kemenlu dan Kemenhan}

Bagaimana silang pendapat antara Kementerian Luar Negeri dengan Kementerian Pertahanan? Dalam catatan sejarah politik luar negeri Indonesia, khususnya sejak reformasi, sering terjadi silang pendapat antara Kemenlu dan Kemenhan dalam politik luar negeri, terutama dalam menyikap dan merespon berbagai peristiwa dan kejadian internasional. Hal ini tercermin dalam setiap pernyataan antara Menlu dan jajarannya dengan Menhan dan jajarannya yang kadangkala tidak sinkron dan seolahseolah terdapat perbedaan sikap, respon, dan kebijakan dalam menanggapi berbagai isu-isu internasional, yang berkonsekuensi logis pada munculnya polemik di ruang publik, yang semakin panas karena disiarkan melalui media massa, khususnya media sosial.

Sebagai contoh pada tahun 2013, terdapat kasus penyadapan yang dilakukan oleh Australia melalui perwakilannya di Indonesia yang menyadap semua pejabat pemerintahan, khususnya Presiden Susilo Bambang Yudhoyono, yang membuat geram seluruh publik di Indonesia. 
Kala itu, sikap Kemenhan yang terepresentasikan melalui Mabes TNI, langsung menyatakan sikap dan membuat pernyataan memutuskan kerjasama militer dengan Australia. Panglima TNI saat itu, Jenderal TNI Moeldoko, tanpa koordinasi dengan berbagai pihak, langsung membuat kebijakan pemutusan hubungan dan kerjasama militer yang selama ini sudah terjalin dengan militer Australia. Panglima TNI saat itu, Jenderal Moeldoko, menyatakan:

Kami dari TNI langsung menghentikan seluruh latihan militer gabungan dengan Australia. Hal ini karena sebagai respon atas aksi penyadapan yang dilakukan oleh Australia.Mulai hari ini langsung kami hentikan. Latihan bersama itu bagian dari mutual trust. Jadi kalau nggak percaya, buat apa kita lakukan latihan bersama.Salah satu latihan gabungan yang kami hentikan adalah Elang Ausindo. Indonesia dalam kesempatan itu mengirimkan enam pesawat F-16 dan rencananya latihan gabungan baru selesai pada 24 November 2013. Tetapi dengan kondisi saat ini, pesawat tersebut harus segera kembali ke tanah air (Antara, 2013).

Namun demikian, hal yang berbeda ditunjukkan oleh Kementerian Luar Negeri, dimana Menteri Luar Negeri saat itu, Marty Natalegawa, masih hanya menarik Duta Besar Indonesia untuk Australia dan menunggu arahan dari Presiden SBY terkait dengan sikap dan kebijakan luar negeri Indonesia dalam menyikapi kasus penyadapan tersebut. Hal ini dibuktikan dengan pernyataan Menteri Luar Negeri, Marty Natalegawa:

Kami memanggil pulang Duta Besar untuk Australia di Canberra guna melakukan konsultasi dan memperoleh informasi tentang apa yang terjadi di Australia. Indonesia telah mempertimbangkan pemanggilan tersebut karena menilai dubes tidak akan dapat melakukan tugas dengan baik di tengah isu penyadapan yang beredar. Pemerintah Indonesia meminta Australia memberikan pernyataan resmi terkait isu penyadapan terhadap Presiden SBY dan berkomitmen untuk tidak melakukan aktivitas serupa itu di masa depan. Terus terang penyadapan adalah sesuatu yang tidak bisa dikecilkan atau diremehkan dampaknya. Kami menunggu sikap dan penjelasan dari pemerintah Austrlia atas penyadapan ini (Republika, 2013).

Silang pendapat antara kedua kementerian ini seharusnya tidak terjadi karena keputusan dan kebijakan untuk memutuskan kerjasama militer antara Indonesia dengan Australia ada pada tangan Presiden, yang seharusnya termanifestasikan dalam Kemenlu RI. 
Kasus serupa terjadi pada bulan Mei 2015, dimana terdapat peristiwa imigran atau pengungsi Rohingya dari Myanmar yang kabur dari negaranya menjadi 'manusia perahu' mengarungi lautan menuju wilayah Indonesia dan Malaysia karena menghindari aksi pembunuhan massal oleh tentara Myanmar. Di saat imigran Rohingya berada di lautan yang mengarah ke wilayah Indonesia, tepatnya akan merapat atau mendarat ke wilayah Aceh, TNI melakukan penghaluan dan mengusir para imigran Rohingya agar tidak mendarat ke wilayah Aceh, padahal mereka dalam kondisi menderita terombang ambing di lautan berbulan-bulan sehingga membutuhkan bantuan kemanusiaan. Kemenhan melalui Panglima TNI saat itu, Jenderal TNI Moeldoko, menyatakan dengan tegas bahwa: "Indonesia tidak memiliki urusan dengan imigran Rohingya, di Indonesia masih banyak orang miskin yang harus diurusi dibandingkan mengurusi imigran Rohingya, dan masuknya imigran Rohingya ke Indonesia dinilai akan menambah beban masalah bagi Indonesia" (Suara, 2015). Sementara itu, Kemenlu menyatakan bahwa Indonesia terikat dalam konvensi internasional tentang pengungsian dan telah sepakat dengan Malaysia untuk memberikan bantuan, pertolongan, dan dukungan kemanusiaan terhadap imigran Rohingnya dengan menyediakan penampungan, pengobatan, dan fasilitas pengungsian lainnya. Hal ini terkonfirmasi dari pernyataan Juru Bicara Kementerian Luar Negeri, Armanatha Nasir, menyatakan:

Bagaimana utamanya tarik mereka (para pengungsi Rohingya) dulu dari tengah laut ke daratan terdekat di sekitar Aceh. Ada kurang lebih 7.000 pengungsi Rohingya yang masih terombang-ambing di laut. Adapun pengungsi yang sudah sampai di Indonesia kurang lebih 1.700 orang. Dukungan internasional sangat diperlukan dalam resettlement, repatriasi, dan bantuan kemanusiaan seperti pemberian makanan. Diharapkan agar para pengungsi yang masuk, 7.000 di laut, masalahnya semuanya bisa diselesaikan. Indonesia berkomitmen untuk membantu manusia perahu dari etnis Rohingnya ditampung di Indonesia dengan alasan kemanusiaan (Kompas, 2015).

Perbedaan pernyataan dan sikap antara Kemenlu dan Kemenhan ini menjadi ironi dalam politik luar negeri Indonesia, dimana seharusnya Kemenhan dan Mabes TNI patuh terhadap kebijakan Kemenlu sebagai ujung tombak dalam politik luar negeri Indonesia.

Peristiwa yang sama terjadi pada Januari 2017, yang mana muncul kasus penghinaan terhadap ideologi Pancasila dalam materi latihan yang ada di pusat pendidikan militer Australia, tepatnya di Perth. Materi latihan mengandung unsur penghinaan terhadap Pancasila, tuduhan TNI sebagai pembunuh massal simpatisan PKI, dan TNI melanggar HAM di Timor Timur, terkuak ke publik sehingga membuat Indonesia geram dan marah terhadap Ausralia. Panglima TNI menyatakan: 
Seorang perwira TNI menemukan, dalam kurikulum militer Australia, ditemukan dukungan pada kemerdekaan Timor Leste dan Papua, serta Pancasila yang diplesetkan menjadi Pancagila. Dugaan pelecehan tersebut ditemukan saat seorang perwira Angkatan Darat mengajar di Australia. Perwira itu mengajar sebagai bagian kerjasama TNI dengan militer negeri kanguru itu (CNN, 2017).

Di tengah ketegangan hubungan antara Indonesia dan Australia karena masalah penghinaan terhadap Pancasila dan TNI tersebut, tidak disangkasangka, Panglima TNI sebagai representasi dari Kemenhan langsung bersikap dengan menyatakan bahwa kerjasama militer Indonesia dengan Australia dihentikan, latihan militer bersama ditinjau kembali, perwira TNI ditarik dari pelatihan dan pendidikan di Australia, dan bentuk kerjasama militer lainnya diputuskan. Panglima TNI, Jenderal TNI Gatot Nurmantyo, menyatakan:

Terlalu menyakitkan penghinaan terhadap Pancasila oleh Australia sehingga tidak perlu dijelaskan. Tentang tentara yang dulu, Timor Leste, Papua juga harus merdeka dan tentang Pancasila yang diplesetkan jadi Pancagila. Oleh sebab itu, saya selaku Panglima TNI memutuskan kerja sama militer sementara waktu dan menarik kembali Kopassus yang tengah bertugas di tempat tersebut (Merdeka, 2017).

Sementara itu, Presiden Jokowi kala itu belum menyatakan sikap apapun, sementara Kemenlu juga masih menunggu sikap dan pernyataan dari Presiden Jokowi. Menteri Luar Negeri, Retno Marsudi mengatakan bahwa:

Penghinaan terhadap ideologi negara, Pancasila, merupakan pelanggaran terhadap kehormatan bangsa dan tidak dibenarkan. Namun, masalah pemutusan hubungan diplomatik masih menunggu arahan bapak Presiden Jokowi, dan saya kira pemutusan hubungan militer dengan militer Australia oleh TNI tidak akan mempengaruhi hubungan diplomatik kedua negara. Kami akan terus mencari jalan terbaik dalam menghadapi masalah ini (Tempo, 2017).

Keputusan Panglima TNI saat itu, Jenderal TNI Gatot Nurmantyo, yang langsung menyatakan pernyataan dan sikap memutuskan kerjasama militer dianggap telah 'off side' karena seharusnya yang berwenang menyatakan pemutusan hubungan militer Indonesia dengan Australia adalah Presiden Jokowi, yang bisa saja didelegasikan ke Kemenlu RI. Koresponden Fairfax di Indonesia yang bernama Jewel Topsfield menulis artikel di koran Sydney Morning Herald, yang inti tulisannya menyesalkan penghentian kerja sama 
militer oleh Panglima TNI secara sepihak:

Keputusan itu tidak dibuat oleh Presiden Joko Widodo. Keputusan untuk memutus kerja sama militer selayaknya dilakukan oleh menteri luar negeri. Jenderal Gatot telah melampaui kewenangannya. Gatot punya ambisi jadi presiden atau wakil presiden. Di saat yang sama banyak orang di militer Indonesia yang tidak suka dengan Jenderal Gatot. Isu ini jadi cara yang bagus buat dia untuk mengharumkan namanya. Keputusan sepihak Gatot memutus kerja sama militer tanpa seizin presiden tidak lazim terjadi dalam suatu hubungan bilateral (Merdeka, 2017).

Kejadian yang tidak jauh berbeda kembali terjadi pada awal Januari 2020 dalam kasus masuknya kapal-kapal nelayan China yang dikawal oleh kapal Cost Guard China masuk ke wilayah perairan ZEE Indonesia di Natuna dan mencuri ikan sehingga membuat ketegangan antara Indonesia dengan China. Kemenlu dengan sangat cepat dan responsif menyatakan bahwa China telah melanggar Hak Berdaulat Indonesia di wilayah ZEE berdasarkan UNCLOS 1982 sehingga China harus menghormati perairan ZEE Indonesia di wilayah perairan Natuna. Kemenlu juga menyatakan bahwa tidak ada kompromi masalah batas wilayah dengan siapapun termasuk dengan China yang mengklaim perairan Natuna sebagai wilayah China berdasarkan doktrin 'nine dash line'. Menteri Luar Negeri, Retno Marsudi, mengatakan bahwa:

Pertama, telah terjadi pelanggaran oleh kapal-kapal Tiongkok (China) di wilayah ZEE Indonesia. Kedua wilayah ZEE Indonesia telah ditetapkan oleh hukum internasional yaitu melalui UNCLOS 1982. Tiongkok merupakan salah satu part (anggota) dari UNCLOS 1982. Oleh karena itu merupakan kewajiban bagi Tiongkok untuk menghormati, implementasi dari UNCLOS 1982. Keempat Indonesia tidak pernah akan mengakui Nine-Dash Line, klaim sepihak yang dilakukan oleh Tiongkok yang tidak memiliki alasan hukum yang diakui oleh hukum Internasional terutama UNCLOS 1982 (CNBC Indonesia, 2020).

Pernyataan tegas dan responsif Kemenlu tersebut berbeda dengan pernyataan Kemenhan, khususnya yang tercermin dari pernyataan Menhan, Prabowo Subianto, yang menyatakan bahwa China adalah negara sahabat, masalah Natuna harus disikapi secara santai dan 'cool', diperlukan negosiasi dan pembicaraan lebih lanjut. Prabowo secara eksplisit mengatakan, "Kita cool saja. Kita santai kok ya. Kita selesaikan dengan baik ya. Bagaimana pun 
Cina negara sahabat. Pasti ada jalan terbaik dan solusi terbaik untuk kasus ini. Jangan terlalu dibesar-besarkan masalah ini"' (Tirto, 2020).

Pernyataan sikap yang jelas-jelas berbeda ini menimbulkan pro dan kontra di tengah masyarakat Indonesia yang mana publi menilai bahwa tidak ada kekompakan, tidak adanya satu sikap yang sama antar pihak di pemerintahan dalam menyikapi kasus Natuna, yang pada gilirannya menambah daftar panjang tidak sinerginya antara Kemenlu dan Kemenhan dalam merespon peristiwa internasional yang patut disayangkan.

\section{Hambatan Kemenlu dan Kemenhan}

Mengapa terjadi silang pendapat antara Kementerian Luar Negeri dengan Kementerian Pertahanan? Dalam melakukan sinergi antara Kementerian Luar Negeri dan Kementerian Pertahanan dalam politik luar negeri, terdapat hambatan dan kendala yang harus diselesaikan antara dua kementerian tersebut agar supaya tidak terjadi silang pendapat lagi. Salah satu kendala yang dihadapi adalah mispersepsi antara Kementerian Luar Negeri dan Kementerian Pertahanan. Kementerian Luar Negerimenganggap bahwa Kementerian Pertahanan kurang memahami politik luar negeri dan hanya memahami urusan pertahanan keamanan semata. Demikian pula sebaliknya, Kementerian Pertahanan menilai Kementerian Luar Negeri tidak memahami urusan pertahanan negara. Sebagai contoh, dalam pembelian alat utama sistem senjata (alutsista), Kementerian Pertahanan hanya melihat kualitas alutsista dan teknologi persenjataannya semata, namun kurang mempertimbangkan konstelasi hubungan antar negara, misalnya jika Indonesia membeli senjata dari Rusia, maka harus dilihat bagaimana sikap Amerika Serikat yang pastinya akan menekan Indonesia dari bidang yang lain, misalnya mengintervensi dalam investasi asing, perdagangan, maupun industri yang masuk ke Indonesia. Hal ini tentunya membuat kerepotan Kementerian Luar Negeri dalam menghadapi tekanan dari Amerika Serikat. Mispersepsi antara dua kementerian ini harus segera dihilangkan dan harus duduk bersama untuk menyatukan persepsi dan menyamakan pandangan tentang politik luar negeri Indonesia, kerjasama luar negeri, dan hubungan diplomatik antar negara.

Masalah lainnya yang perlu mendapatkan perhatian dan pembahasan antar dua kementerian ini adalah persoalan alokasi anggaran untuk Atase Pertahanan (Athan) yang selama ini disalurkan langsung dari Kementerian Pertahanan ke Athan tanpa melalui Kementerian Luar Negeri. Hal ini berbeda dengan atase lainnya, misalnya atase perdagangan, atase perindustrian, atase ketenagakerjaan, atase kepolisian, dan lain-lain yang proses penyaluran anggarannya melalui Kementerian Luar Negeri. Sebagai contoh, atase perdagangan yang ditempatkan di setiap KBRI di luar negeri, dimana alokasi anggarannya dari Kementerian Perdagangan disalurkan 
melalui Kementerian Luar Negeri, untuk kemudian diteruskan ke KBRI, yang kemudian diterima oleh Atase Perdagangan di luar negeri. Perbedaan alokasi anggaran untuk Athan yang proses administrasi penyaluran anggarannya yang berbeda sendiri dengan atase lainnya harus segera dibahas untuk disepakati bersama antara dua kementerian ini.

Kendala lainnya yang sering muncul, meskipun tanpa disadari, adalah masalah romantisme masa lalu dimana Kementerian Pertahanan merupakan kementerian yang powerful, khususnya di era Orde Baru, sehingga masih ada ego sektoral yang kuat, perasaan sebagai kementerian penting, kementerian yang besar, dan kementerian yang bersifat rahasia, yang pada akhirnya menyulitkan untuk melakukan sinergi, koordinasi, komunikasi, dan kolaborasi. Simela Victor Muhamad (2015), menyatakan bahwa dalam kasus etnis Rohingya, Menteri Pertahanan RI, Ryamizard Ryacudu, secara tegas berpandangan bahwa: 'Kementerian Pertahanan selalu mengutamakan kepentingan bangsa dan negara, khususnya kedaulatan negara, sehingga harus hati-hati dalam menerima dan menampung pengungsi etnis rohingya, yang tentunya ini berbeda dengan Kementerian Luar Negeri yang selalu terbuka terhadap pengungsi atas nama kemanusiaan internasional dan hukum internasional'. Selama ini, Kementerian Pertahanan sudah biasa melakukan terobosan kerjasama luar negeri, khususnya di bidang pertahanan keamanan dengan negara lain, termasuk pembelian alutsista, diplomasi pertahanan, dan diplomasi militer lainnya, yang dilakukan kadangkala tanpa melibatkan Kementerian Luar Negeri, sehingga terkesan kurang memperdulikan eksistensi dan kewenangan dari Kementerian Luar Negeri dalam menjalankan politik luar negeri. Hal ini dibuktikan dalam perencanaan pembelian 11 pesawat Sukhoi Su-35 dari Rusia di awal bulan Januari 2020 lalu, dimana Kementerian Pertahanan tidak ada komunikasi intensif dan pembahasan dengan Kementerian Luar Negeri, yang pada akhirnya membuat gusar Amerika Serikat dan Presiden Donald Trump melakukan intervensi kepada Pemerintah Indonesia untuk menggagalkan rencana pembelian pesawat tempur tersebut.

Ditambah lagi dengan adanya kenyataan dimana kedua kementerian belum menyadari bahwa sinergi antara dua kementerian adalah keharusan. Diplomasi memerlukan back up dari militer/Kementerian Pertahanan. Salah satu penentu keberhasilan diplomasi yang digelar oleh Kementerian Luar Negeri adalah adanya kekuatan deterrence yang menjadi semacam 'senjata pamungkas' bagi para diplomat untuk menggertak dan mengancam lawan diplomasi, sehingga diperlukan sinergi antara Kementerian Luar Negeri dengan Kementerian Pertahanan, untuk sama-sama saling mendukung bagi terselenggaranya diplomasi Indonesia yang kuat. Kementerian Pertahanan juga harus menyadari bahwa dibutuhkan Kementerian Luar 
Negeri, khususnya dalam menggelar diplomasi pertahanan di berbagai forum internasional untuk mengangkat citra Indonesia.

\section{Sinergi Kemenlu dan Kemenhan}

Bagaimana langkah yang harus dilakukan agar terwujud sinergi antara Kementerian Luar Negeri dengan Kementerian Pertahanan? Sudah saatnya antara Kementerian Luar Negeri dan Kementerian Pertahanan menghilangkan silang pendapat tentang urusan pernyataan dan sikap dalam merespon berbagai peristiwa dan permasalahan hubungan luar negeri, kebijakan luar negeri, dan politik luar negeri. Kedua kementerian duduk bersama untuk mendiskusikan dan membahas kesepakatan dan kesatuan pandangan dalam menjalankan politik luar negeri yang bebas aktif, tanpa adanya kegaduhan dan terkesan tidak kompak dalam urusan kebijakan luar negeri. Sinergi antara Kementerian Luar Negeri dan Kementerian Pertahanan sudah selayaknya dibangun dari sekarang dengan mendesain kebijakan satu pintu dalam politik luar negeri, sehingga akan terwujud kekompakan dan kesolidan antar pemangku kepentingan dalam perumusan dan penerapan politik luar negeri Indonesia.

Sinergi antara Kementerian Luar Negeri dengan Kementerian Pertahanan dapat dimulai dengan jalinan silaturahmi, komunikasi, koordinasi, kolaborasi antara pejabat kementerian kedua pihak. Sudah seharusnya dibentuk forum koordinasi antar pejabat di Kementerian Luar Negeri dan Kementerian Pertahanan yang beranggotakan pejabat eselon 1 dan eselon 2, melakukan rapat koordinasi setiap bulan untuk membahas perkembangan terkini, melakukan analisa permasalahan internasional yang berdampak pada Indonesia, serta ajang saling bertukar informasi, tukar pendapat dan sharing gagasan tentang politik luar negeri yang terkait dengan pertahanan negara. Forum koordinasi tersebut juga dapat dijadikan sebagai sarana saling mengenal dan saling silaturahmi, yang dapat menjadi bekal untuk memudahkan koordinasi ke depannya jika ada masalah kebijakan luar negeri yang menyangkut urusan pertahanan negara.

Integrasi pendidikan dan pelatihan yang terkait dengan pendidikan dan pelatihan (diklat) diplomat dan diklat Athan perlu diwujudkan untuk menyatukan materi tentang politik luar negeri, hubungan bilateral, kerjasama militer antar negara, dan urusan lainnya. Sudah saatnya pejabat Kementerian Pertahanan menjadi narasumber, pembicara, trainer, guru atau dosen dalam diklat diplomat. Demikian pula sebaliknya, pejabat dari Kementerian Luar Negeri menjadi guru/dosen/pengajar/trainer dalam kursus Athan di Kementerian Pertahanan, khususnya di BAIS TNI, sebagai lembaga militer yang menyelenggarakan Diklat Athan. Dirancang pula antara peserta diklat diplomat dan peserta kursus Athan melakukan kegiatan bersama selama beberapa pekan atau pekan kegiatan bersama untuk saling 
mengenal, saling silaturahmi, dan saling mengikatkan hubungan emosional, yang sangat penting sebagai bekal dalam menjalankan tugas di luar negeri, ketika kelak antara diplomat dan Athan ditempatkan di perwakilan luar negeri memudahkan untuk koordinasi dan bekerja dalam sebuah tim.

Antara Kementerian Luar Negeri dan Kementerian Pertahanan sudah seharusnya diadakan perwira penghubung/petugas penghubung/ liaison officer, dimana pejabat dari Kementerian Luar Negeri ditempatkan di Kementerian Pertahanan dan begitu pula sebaliknya pejabat dari Kementerian Pertahanan ditempatkan di Kementerian Luar Negeri untuk menjembatani berbagai jalur komunikasi dan koordinasi antara dua kementerian, berfungsi menghilangkan sekat dan hambatan komunikasi, serta menghapus ego sektoral dan prasangka negatif antar dua kementerian dalam menggelar politik luar negeri maupun dalam mensikapi berbagai permasalahan hubungan antar negara yang terkait dengan urusan pertahanan negara. Perwira penghubung dapat menjadi jembatan antara kedua kementerian dalam menerapkan politik luar negeri yang bebas aktif secara solid dan terpadu.

Pemberdayaan forum diplomat di Kementerian Luar Negeri dan forum Athan di Kementerian Pertahanan, khususnya di BAIS TNI, harus terus ditingkatkan, dimana forum diplomat dan forum Athan harus disinergikan melalui pertemuan rutin, komunikasi intensif, dan koordinasi berkala, untuk membahas isu-isu internasional terkini, dampaknya terhadap Indonesia dan upaya mengantisipasinya, sehingga akan mampu menyatukan pandangan dan menyamakan persepsi antara diplomat dan Athan sebagai representasi dari Kementerian Luar Negeri dan Kementerian Pertahanan. Kegiatan riset bersama antar Puslitbang kedua kementerian perlu digalakkan, seminar bersama, lokakarya bersama, dan Focus Group Discussion (FGD) kolaborasi antar dua kementerian merupakan kegiatan penting yang sudah saatnya dilakukan bersama sama, kolaboratif, dan inovatif.

Dalam penugasan di lapangan, tentunya antara militer (khususnya Athan) dengan diplomat harus saling mengenal untuk memudahkan koordinasi dan komunikasi di wilayah penugasan di luar negeri, sehingga diperlukan sinergi dalam pendidikan, latihan, dan pembinaan baik diplomat maupun Athan antara Kementerian Pertahanan dan Kementerian Luar Negeri. Dalam kaitan dengan militer dan diplomat, secara teori dan prinsip universal, militer berada di bawah komando Kementerian Pertahanan, sedangkan diplomat berada di bawah garis komando Kementerian Luar Negeri. Dengan begitu, dapat ditegaskan bahwa antara Kementerian Pertahanan dan Kementerian Luar Negeri di suatu negara harus berjalan secara seiring, seirama, dan senada, dalam setiap kebijakan dan politik luar negeri suatu negara. Kementerian Pertahanan memiliki kewenangan 
dalam mengelola sumber daya militer dan Kementerian Luar Negeri yang mempunyai otoritas dalam penggelaran kekuatan diplomat, harus berjalan beriringan untuk mencapai kepentingan nasional yang sama. Terlebih lagi, di setiap kantor perwakilan diplomatik, misalnya di setiap kedutaan terdapat Atase Pertahanan alias Athan, yang bertanggungjawab kepada Duta Besar. Antara Kementerian Pertahanan dan Kementerian Luar Negeri harus mampu bersinergi karena memiliki karakteristik yang saling melengkapi dan saling mengisi, sebagaimana dapat dilihat pada tabel 1 berikut ini:

Tabel 1

Sinergi Kementerian Pertahanan dan Kementerian Luar Negeri

\begin{tabular}{|l|l|l|}
\hline \multicolumn{1}{|c|}{ Unsur } & \multicolumn{1}{|c|}{ Kementerian Pertahanan } & \multicolumn{1}{|c|}{ Kementerian Luar Negeri } \\
\hline Pimpinan & Menteri Pertahanan (Menhan) & Menteri Luar Negeri (Menlu) \\
\hline Pilar Utama & Militer & Diplomat \\
\hline Fungsi Pokok & Tempur & Diplomasi \\
\hline $\begin{array}{l}\text { Menjadi Terdepan } \\
\text { pada Kondisi }\end{array}$ & Perang & Damai \\
\hline Pendekatan & Fisik (konflik dan kekerasan) & $\begin{array}{l}\text { Non Fisik (persuasi dan } \\
\text { negosiasi) }\end{array}$ \\
\hline Tempat / Medan & $\begin{array}{l}\text { Laut, Udara, Darat (hutan, } \\
\text { gunung, lembah, dll) }\end{array}$ & $\begin{array}{l}\text { Meja Perundingan (hotel, resort, } \\
\text { gedung konvensi, dll) }\end{array}$ \\
\hline
\end{tabular}

Adapun dampak positif dari sinergi antara dua kementerian dalam perumusan kebijakan luar negeri Indonesia adalah terwujudnya kebijakan politik luar negeri yang transparan, akuntabel, partisipatif dan komprehensif, mempertimbangkan aspek kepentingan sipil dan militer, khususnya dalam diplomasi pertahanan, terutama dalam merespon setiap peristiwa keamanan internasional. Selain itu, sinergi antar dua kementerian tersebut akan mampu melahirkan politik luar negeri yang kuat dan tangguh dimana diplomat yang menjalankan kebijakan luar negeri akan mendapatkan dukungan dan back up dari kekuatan militer, khususnya atase pertahanan yang ada di seluruh kantor perwakilan diplomatik Indonesia di luar negeri. Akhirnya, sinergitas dua kementerian ini akan menciptakan kekuatan baru dalam diplomasi pertahanan (confidence building measures, military capability, defence industry) Indonesia di masa mendatang. 


\section{Kesimpulan}

Dalam terminologi politik luar negeri, Kementerian Luar Negeri merupakan lembaga pemerintahan yang sangat vital dalam menentukan keberhasilan politik luar negeri suatu negara. Kementerian Luar Negeri yang didalamnya terdapat kantor perwakilan di luar negeri dengan ujung tombaknya adalah para diplomat merupakan kekuatan utama dalam menggelar diplomasi untuk meningkatkan citra Indonesia di mata internasional, sekaligus mewujudkan kepentingan nasional Indonesia. Kementerian Luar Negeri harus mampu memformulasikan dan menerapkan politik luar negeri secara piawai dan fleksibel melalui penggelaran diplomasi yang efektif dan efisien, dengan memberdayakan berbagai perwakilan diplomatiknya di luar negeri.

Politik luar negeri Indonesia yang bebas aktif selama ini di jalankan oleh Kementerian Luar Negeri RI secara profesional di tengah lingkungan politik global yang sering mengalami turbulensi dan konstelasi global yang berubah cepat. Dalam menjalankan politik luar negeri, Kementerian Luar Negeri belum sinergis dengan Kementerian Pertahanan, dimana Kementerian Pertahanan justru sering melakukan kebijakan luar negeri, khususnya kebijakan pertahanan negara, dan kerjasama militer dengan negara lain yang kurang berkoordinasi dengan Kementerian Luar Negeri. Kementerian Pertahanan sering dikatakan "off side" dalam membuat pernyataan tentang kebijakan pertahanan negara kaitannya dengan negara lain tanpa melalui diskusi dan koordinasi dengan Kementerian Luar Negeri.

Serangkaian hambatan dihadapi oleh Kementerian Pertahanan dan Kementerian Luar Negeri dalam melakukan sinergi, komunikasi, koordinasi, dan kolaborasi dalam membahas hubungan pertahanan dan hubungan militer antar negara ataupun dalam menanggapi isuisu internasional, khususnya ego sektoral antar kedua kementerian, mis persepsi, dan mis komunikasi sehingga diperlukan langkah dialog, diskusi, dan pembentukan forum-forum yang mempertemukan antara pejabat di kedua kementerian, sehingga akan mencapai satu kesepakatan dan kesamaan pandangan dalam melihat hubungan internasional, hubungan luar negeri, dan kerjasama militer antar negara secara solid dan terintegrasi. Kementerian Luar Negeri harus dijadikan sebagai satu-satunya kementerian yang berwenang dalam urusan luar negeri melalui kebijakan luar negeri satu pintu, dimana kementerian lain, termasuk kementerian Pertahanan sebagai kementerian pendukung yang mendukung Kementerian Luar Negeri dalam merumuskan dan menerapkan politik luar negeri.

Oleh karena itu, direkomendasikan kepada Kementerian Luar Negeri dan Kementerian Pertahanan untuk saling terbuka, saling percaya, dan saling mendukung dalam perumusan kebijakan luar negeri, khususnya di tingkat pejabat senior, misalnya pejabat eselon I dan eselon II untuk 
saling berkomunikasi, koordinasi dan kolaborasi baik yang bersifat formal maupun informal untuk membuat nota kesepahaman, MoU ataupun Code of Conduct yang mengatur bentuk, sifat, wujud, program, dan kegiatan sinergi antara dua kementerian tersebut.

\section{Daftar Pustaka}

Ambarwati \& Wijatmadja, S. (2016). Pengantar Ilmu Hubungan Internasional. Malang: Cita Intrans Selaras.

Antara (2013), Buntut penyadapan, RI evaluasi hubungan diplomatik [Online]. Tersedia dalam: <https://bengkulu.antaranews.com/ berita/19934/buntut-penyadapan-ri-evaluasi-hubungan-diplomatik> [Diakses 2 Januari 2020].

Clausewitz, C.V. (1984). On War. New York: Oxford University Press.

CNBC Indonesia (2020) Ini kronologis RI protes keras klaim China soal Natuna [Online]. Tersedia dalam: <https://www.cnbcindonesia.com/ news/20200104193648-4-127681/ini-kronologis-ri-protes-keras-klaimchina-soal-natuna $>$ [Diakses 20 April 2020].

CNN Indonesia (2017), Ryamizard: Tentara Australia Penghina Pancasila SudahDihukum [Online]. Tersedia dalam: $<$ https://www.cnnindonesia. com/nasional/20170104184455-12-184141/ryamizard-tentara-australiapenghina-pancasila-sudah-dihukum $>$ [Diakses 20 Januari 2020].

Covey, S.R. (1989). The Seven Habits of Highly Effective People. New York: Simon and Schuster.

Detik (2015), Penjelasan Panglima TNI Soal Penghalauan Pengungsi Rohingya ke Indonesia [Online]. Tersedia dalam: <https://news.detik. com/berita/2920335/penjelasan-panglima-tni-soal-penghalauanpengungsi-rohingya-ke-indonesia?n991104466=> [Diakses 2 Januari 2020].

Eby Hara, A. (2011). Analisis Politik Luar Negeri. Bandung: Nuansa.

Jackson, R. \& Sorensen, G. (2009). Pengantar Studi Hubungan Internasional. Yogyakarta: Pustaka Pelajar.

Jemadu, A. (2008). Politik Global dalam Teori dan Praktek. Yogyakarta: Graha Ilmu.

Kompas (2015), Panglima TNI Diingatkan untuk Tak Beri Pernyataan Kontroversial soal Rohingya [Online]. Tersedia dalam: <https:// nasional.kompas.com/read/2015/05/21/12292781/Panglima.TNI. Diingatkan.untuk.Tak.Beri.Pernyataan.Kontroversial.soal.Rohingya> [Diakses 1 Januari 2020].

Merdeka (2017), Tegasnya Panglima TNI ketika Australia hina Pancasila [Online]. Tersedia dalam: <https://www.merdeka.com/peristiwa/ tegasnya-panglima-tni-ketika-australia-hina-pancasila.html> [Diakses 11 Januari 2020].

Republika (2013) Marty panggil pulang dubes RI untuk Australia [Online]. 
Tersedia dalam: <https://republika.co.id/berita/mwgj4f/martypanggil-pulang-dubes-ri-untuk-australia> [Diakses 11 januari 2020].

Sitepu, A. (2011). Studi Hubungan Internasional. Yogyakarta: Graha Ilmu.

Suara(2015), SikapPanglima TNISoalPengungsi Rohingya Dikecam [Online].

Tersedia dalam: <https://www.suara.com/news/2015/05/21/140045/ sikap-panglima-tni-soal-pengungsi-rohingya-dikecam> [Diakses 5 Januari 2020].

Suryohadiprojo, S. (2005). Sivis Pacem Para Bellum: Membangun Pertahanan Negara Yang Modern dan Efektif. Jakarta: Gramedia Pustaka Utama.

Tempo (2017) Kasus penghinaan Pancasila militer Australia, ini kata Retno [Online]. Tersedia dalam: <https://nasional.tempo.co/read/833525/ kasus-penghinaan-pancasila-militer-australia-ini-kata-retno> [Diakses 5 Januari 2020].

Tirto (2020) Sikap Prabowo 'santai' respons kisruh Natuna: Cina negara sahabat [Online]. Tersedia dalam: <https://tirto.id/sikap-prabowosantai-respons-kisruh-natuna-cina-negara-sahabat-eqol> [Diakses 20 April 2020].

Wuryandari, G. (2009). Format Baru Politik Luar Negeri Indonesia. Jakarta: LIPI. 